\title{
The politics of giving
}

\section{Anne-Emanuelle Birn reviews a survey of the new megaphilanthropy and its impact.}

$\mathrm{I}$ January, Oxfam released its annual zinger on inequality: the collective net worth of the world's poorest half (3.6 billion people) is equivalent to that of just 8 of the wealthiest men. This figure was released to coincide with the yearly gathering in Davos, Switzerland, of economic and political elites and celebrities, who publicly commit to advancing global well-being even as they safeguard conditions for private profiteering.

Each of the eight wealthiest men is a megaphilanthropist, underwriting billions of dollars for medical research, public health, humanitarian causes and education. The bulk are familiar US names, including technology gurus Bill Gates, Mark Zuckerberg and Lawrence Ellison, investment oracle Warren Buffett, Amazon founder Jeff Bezos and media magnate (and politician) Michael Bloomberg. Health is much in their sights: Zuckerberg has earmarked US $\$ 3$ billion to "cure, prevent or manage" disease; Bloomberg has designated almost $\$ 1$ billion to curb smoking and traffic fatalities; and Gates has ploughed some $\$ 20$ billion into vaccine development and global health. This group - with many others in the top tier of the \$700-billion US philanthropic sector - is the subject of David Callahan's exposé, The Givers.

As Callahan reveals, many philanthropists participate in the Giving Pledge, a brainchild of Gates and Buffett that invites the world's wealthiest to contribute the majority of their assets to addressing "society's most pressing problems", echoing steel tycoon Andrew Carnegie's 1889 homily 'The Gospel of Wealth' Drawing on insider interviews, Callahan discovers that many pledgers are initially humble about giving. This contrasts with the arrogance enabling their profitmaking journeys, which spills over into a sense of "hyperagency" - sociologist Paul Schervish's term for elites' sense of entitlement.

Callahan goes beyond such sentiments to explore the scientific, social and political implications of largesse in the new gilded age.
His breathless overview of the provenance, giving style and domestic impact of current US philanthropy finds it undemocratic. Most egregiously, this set-up heightens private influence in an era of plunging public spending. Not all philanthropists are anti-government. Buffett calls for increased taxes; Bloomberg wants philanthropy

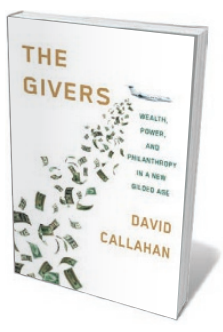

The Givers:

Wealth, Power, and Philanthropy in a New Gilded Age

DAVID CALLAHAN Alfred A. Knopf: 2017. to "embolden", not replace, government. Still, both continue to marshal soaring wealth while their donations mount, making them absurd reformers of the system that empowers them.

Older-style "legacy" philanthropy (exemplified by New York City's Rockefeller Foundation) was based on slow accumulation from mainline industries, with late-in-life or posthumous creation of perpetual, bureaucratized

\section{MANY WOULD ARGUE THAT IT IS TIME TO REIN IN THE BILLIONAIRES.}

foundations. Callahan is more interested in those with fast and vast fortunes derived from finance and technology. Overnight tycoons prefer to 'give while they live', spending down huge fortunes with huge donations. Their venture philanthropy is characterized by risktaking, mirroring the donors' own business trajectories to big bucks - leaving room for both colossal failure and large-scale impact. It often bypasses traditional support for educational and cultural institutions to invest in catalysing issues, including gene editing and artificial intelligence.

Philanthropy remains gendered: men earn fortunes and their wives or daughters give them away, with little focus on gender equity beyond reproductive rights. Still, women's philanthropic networks (such as Women Moving Millions, based in New York City) have emerged, perhaps portending change around women's political representation.

Callahan marvels at the ideological range of philanthropic giving. Firmly for or against issues ranging from the 2010 US Affordable Care Act to climate change, it also spans support of both liberal and conservative think tanks such as, respectively, the Center for American Progress and the libertarian Cato Institute, both in Washington DC. (Thinktank funding is a savvy way of bypassing laxly enforced prohibitions on political lobbying by non-profit institutions.) Yet Callahan is troubled that the donors' agenda-setting priorities do not reflect the public's. He believes that philanthropists are more fiscally conservative and socially liberal than the general population, and are stronger advocates of market solutions and technocratic fixes. Thus they typically favour the latest medical innovation over ensuring decent housing conditions.

Callahan's discussion of science and medicine is circumscribed. One concern is that therapies for the wealthy, such as precision oncology, garner undue attention. Prospects for accelerating research where government grant-making is bureaucratic and cautious, he fears, are accompanied by spending cuts leading to the privatization of science. Callahan says little about the impact of such changes, but foreseeable problems include ratcheting down peer-review processes and ignoring already underfunded arenas such as occupational health.

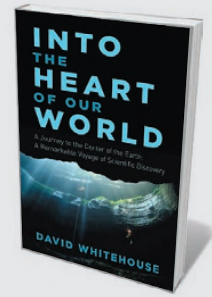

Into the Heart of Our World

David Whitehouse (Pegasus, 2017)

In this vivid imagined trek into our planet's depths, science journalist David Whitehouse details the technological advances that are making possible astonishing discoveries, from the origins of seismology to the bacteria living deep in Earth's crust.

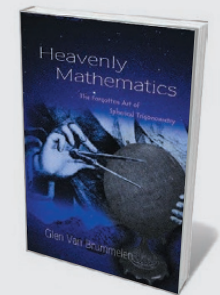

Heavenly Mathematics

Glen Van Brummelen (Princeton Univ. Press, 2017) Once a mainstay of mathematics, spherical trigonometry no longer appears on school curricula. Here, Glen Van Brummelen reasserts the field's importance, sharing in illuminating detail how it figured in astronomy, cartography and our understanding of Earth's rotation. 
One of the most contentious targets of activist philanthropy is education. Among others, the Walton family - heirs to the Walmart fortune - Zuckerberg and hedge-fund maestro Bill Ackman have given enormous sums to charter schools, facilities that are publicly funded, privately administered and sometimes for-profit. Illustrating how fraught this philanthropic involvement is, in Newark, New Jersey, a top-down school-reform strategy disregarded community priorities, generated wide resentment, exacerbated inequity and defunded public schools.

Despite his lament that increasingly powerful philanthropy engenders civic inequality, Callahan pays inadequate attention to philanthrocapitalism. This model, which infuses business principles into philanthropy (proffering handsome investment returns), essentially justifies wealth accumulation on the backs of ordinary people. He mentions various structural enablers of gargantuan fortunes, from tax shelters to weak securities laws and corporate pressure to cut taxes and shrink regulation. Yet he retreats to mild critique, calling for a "balancing act" of middling reforms around philanthropic accountability, transparency, partnerships and political lobbying.

If philanthropy indeed poses a grave threat to egalitarian values, Callahan's prescription may amount to tinkering at the margins. Why should self-anointed philanthropic elites, who already exercise inordinate power, have carte blanche to steer public policy? As former US labour secretary Robert Reich has noted, governments once collected billions from tycoons, then democratically redistributed these revenues. Many would argue that it is high time to rein in the megabillionaires, whether they are wielding influence from the boardroom, the White House or philanthropic perches.

Anne-Emanuelle Birn is professor of critical development studies and social and behavioural health sciences at the University of Toronto in Canada. Her latest book is Oxford University Press's Textbook of Global Health. e-mail:ae.birn@utoronto.ca

\section{METEOROLOGY}

\section{Weather makers}

\section{Jim Fleming assesses a history of US governmental intervention in the atmosphere.}

"M in the nineteenth and twentieth centuries. Yet their decrees carried little weight in the aerial realm: the atmosphere does not respond to state control.

In Make It Rain, historian Kristine Harper treats weather control as a political agent in the hands of the American state. Politicians at local, state and national levels issued edicts in pursuit of their political ends to bring enhanced 'sky water' to their thirsty districts, or to mobilize the clouds for diplomatic or military ends; "entrepreneurial scientists" took their money and produced technical reports. But in the long run, the weather did what the weather does.

In an overextended metaphor belying the complexity of her narrative, Harper asks us to imagine the state as "a shadowy male figure" lurking at the edges of technical and environmental histories: "Do we invite him in, take his money, let him 'meet the parents', acknowledge that he is calling the shots, and then continue checking in with him to make sure he hasn't trotted off with a more attractive partner...?" Her work is informed by political scientist James C. Scott's Seeing like a State (Yale Univ. Press, 1998), which criticizes the administrative ordering of nature and society by the state. It also echoes sociologist Theda Skocpol's admonishment to "bring the state back in" - in the book of the same name, co-edited with Peter B. Evans and Dietrich Rueschemeyer (Cambridge Univ. Press, 1985) - when describing efforts to control nature.

The strongest sections of Make It Rain include an account of GROMET, the code name for a secret agricultural rainmaking project run by the United States in India during the administration of US president Lyndon Johnson, in 1967. GROMET

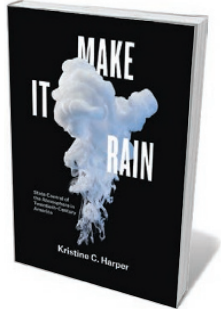

Make It Rain: State Control of the Atmosphere in Twentieth-Century America

KRISTINE C. HARPER University of Chicago Press: 2017. provided a diversion and a cover story for the testing of silver iodide cloud seeding, slated to be used in the Vietnam War. Here, an interesting cast of characters from the 1960s appears, made up of big government figures not typically included in histories of science: Bureau of Reclamation director Floyd Dominy, US ambassador to India Chester Bowles, secretary of state Dean Rusk, agriculture secretary Orville Freeman, national-security adviser Walt Rostow and CIA director Allen Dulles.

Yet Harper includes no parallel analysis of earlier bureaucrats and no mention of president Richard Nixon's continuation of weather-modification programmes over Vietnam. She provides a helpful list of weather-control bills passed by Congress in the period 1947-53, and a list of weathercontrol research projects conducted in more than a dozen countries in the 1950 s - but these lack detailed analysis.

Harper indicates, in several places, that weather control is actually possible. Most meteorologists would disagree. She cites the "earliest success" as occurring in 1921, "when an airplane dispersing [electrically] charged sand into clouds triggered a snow flurry". This was an Army Air Corps-sponsored project in Dayton, Ohio, that produced no reliable scientific results. Later, she writes that "as a result" of silver iodide seeding in 1961, Hurricane Esther's barometric pressure "stopped deepening and maintained a relative constant pressure thereafter". She also cites

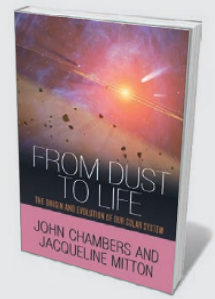

From Dust to Life John Chambers \& Jacqueline Mitton (Princeton Univ. Press, 2017)

In this grand chronicle of the science behind the origins of our 4.6-billion-year-old Solar System, John Chambers and Jacqueline Mitton peruse everything from the giant collision thought to have formed our Moon to the nature of meteorites.

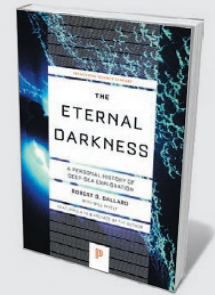

The Eternal Darkness

Robert D. Ballard \& Will Hively (Princeton Univ. Press, 2017)

Globally, just $1 \%$ of the sea floor has been explored in detail. Robert Ballard and Will Hively's exploration of that unforgiving environment reveals how divers reach it, and uncovers amazing beasts, such as blind white crabs and giant clams. 